\title{
Rational Decision Making: Structuring of Design Meetings
}

\author{
HUGO J. W. VLIEGEN AND HERMAN H. VAN MAL
}

\begin{abstract}
Designing from the view-point of decision making is discussed. In sorting design problems the stages strategy, tactics, and execution, called the decision making cycle, must always occur, it is assumed. Particular design meetings are included in this decision making cycle to obtain improved structuring of the design process. These meetings play an essential role in promoting good communication between designers and other interested parties. The design meetings include decision analysis (DA), potential problem analysis (PPA), failure mode and effect analysis (FMEA) and design for production (DFP) in a described way. Furthermore, progress controls in the decision making cycle, are included which should ensure faster feedback about the progress of a project involving checks of the management aspects quality, throughput time and costs. The necessity of this approach by means of data gathered from an industrial automation department is illustrated.
\end{abstract}

\section{INTRODUCTION}

A A RESULT of changes in market conditions the lifeAcycles of product types and related production equipment become shorter and the pressure on the throughput time of product renewal increases. Because of this, there is growth in the demands made on the controllability of design processes involving quality, throughput time, and costs.

Hemels and van Mal [6], in a recent publication, have applied rational decision making [11], [12], [14] as an organizational concept to the design range of products and processes and showed that this approach can be very useful for increasing the controllability of the design process. The attention of the designer can be more focussed on the creation of proper solutions rather than spending time on redoing designs because of poor decision making. In this paper it is proposed to integrate rational decision making, methodical designing, particular design meetings and progress controls.

We assume that in solving problems the following three stages in the so called, decision making cycle, must always occur [13], [14]: strategy, tactics, and execution, by which improved structuring is obtained. For promoting good communication between designers and other participants in the design process we will introduce design meetings in the decision making cycle. These particular meetings play an essential role in systematically gathering relevant design information. During these meetings interested parties, e.g., service and production, will criticize the design from their view-point. The particular

Manuscript received February 29, 1988; revised June 1989. The review of this paper was processed by Editor D. F. Kocaoglu.

H. J. W. Vliegen is with Philips Corporation. Small Domestic Appliance Division, P.O. Box 25, 9700 AE Groeningen, Eindhoven, The Netherlands. H. H. van Mal is with Eindhoven University of Technology, P.O. Box 513. (Paviljoenc) $5600 \mathrm{MB}$ Eindhoven, The Netherlands.

IEEE Log Number 9034800. design meetings with different character can include decision analysis (DA) [7], [8], [11], [12], potential problem analysis (PPA) [11], [12], failure mode and effect analysis (FMEA) [19] and design for production (DFP). DA involves the systematic evaluation of alternative solutions against objectives. In a PPA the potential adverse consequences of alternatives are compared. In a FMEA the failure behavior of possible solutions are studied. Design for production, DFP, involves the producibility of proposed solutions.

If we combine the decision making cycle with methodical designing [2], [5], [9], [13], [17] we can indicate the position of the particular design meetings with their special character within the decision making cycle. Methodical designing is a technique to solve (technical) problems in a structured way, whereby the design process is consciously passed through.

Starting with a practical example from mechanical engineering [18], we shall illustrate in this article the extent to which the design process can get out of hand as regards quality, throughput time and costs, to stress the necessity for the improved decision making.

Further we shall consider designing as a complex decision making process and illustrate the complexity of design activities from this point of view. In addition we shall consider the exact position of the design meetings, like DA, PPA, FMEA, and DFA, within the decision making cycle.

In conclusion, we will consider the role of the computer within this framework.

\section{Management Aspects}

The management aspects quality, throughput time and costs [6], [16] are the criteria for judging industrial productivity. The activity is judged to have been adequately managed if it meets the criteria for quality, time and costs. In other words, the result of the design activity must meet the preset quality standards, it must be available at the required time, and the costs involved must not exceed the budget estimate. Of course, the quality standards will not remain constant over the duration of the design process, exposed as they are to possible changes in their environment.

In order to judge the extent to which the design process of production equipment, e.g., industrial automation, has been well managed, the following significance is attached to the aspects given below. The quality of the design process becomes measurable when the production equipment is put into use and the expectations for its planned operational life are met or not. This requires permanent feedback about the way it functions, including, e.g., recording of the mean time between failures 


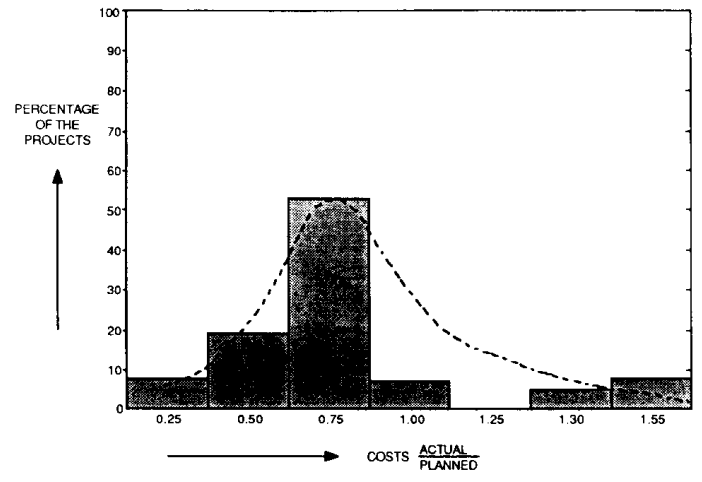

Fig. 1. Ratio of actual and planned costs.

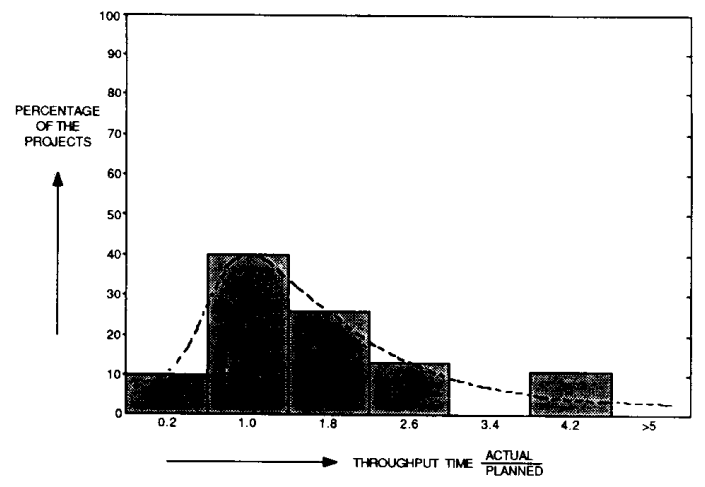

Fig. 2. Ratio of actual and planned throughput time.

of the production equipment supplied [10]. Unfortunately it takes a very long time to get insight into the quality aspects of production equipment. The throughput time, in this article the development time, relates to the time between the start of the design and the moment that the production equipment becomes available to the production area. The costs for development cover the required capacity and material for designing the production equipment.

\section{Practical Example Involving Time and Costs}

The data from the practical example given below refer to the whole design range from conception to delivery of production equipment. Data about the function of the production equipment during operation were not available. Therefore we cannot judge the quality of the design process of the different projects in this example. We will restrict ourselves to discussing the costs and throughput time aspects.

The realization of the projects considered in this research generally involved several man-years and the throughput time often covered more than one year. The data available are the basis of Figs. 1 and 2.

In Fig. 1 we see that in less than 20 percent of the projects the budgeted costs were exceeded. This is probably the result of the way we interpreted the available data. We assumed that the total final budget of a given project covers the estimated project costs, and that no costs were booked on other com- mission numbers. In view of the often occurring decisions to adapt the initial budget this assumption may however be unrealistic in practice. Fig. 2 shows that the planned throughput time was exceeded considerably in many cases.

If we do not assume that the final budget is representative of the estimated costs, then the phenomena described above can be explained by one or more of the following causes:

1) insufficient experience in determining a realistic throughput time and setting up a feasible cost budget;

2) lack of design capacity, thus making it necessary to spread the project out over a longer period of time;

3) lack of a project-oriented organization so that the work on given projects can come to a stop unnoticed;

4) adverse effects on throughput time because of too frequent modifications of the specifications at an advanced stage of the project.

The design capability of the industrial automation department can be characterized as follows. About 50 designers excluding the persons in the workshop and test laboratories, with a high education level and skill think out new concepts, design and make detailed drawings of components of complete machine groups. The yearly output is roughly ten highly automated complex manufacturing systems (machine groups). The industrial automation department is part of a big manufacturer of consumer products.

\section{Designing as a Decision Making Process}

If we regard designing as a complex decision making process, the analysis of existing design processes is possible on the basis of decision making models. The Mintzberg model [15] is one in which every decision making process begins with stimuli to take action; the end result of the decision making process is the appropriate action. This general model assumes that any decision process includes the recognition of problems and opportunities, diagnosis of problems, search for and design of alternative solutions and selection by judgment, analysis and discussion of the most useful solution.

Fig. 3 shows the course of decision making in one actual case of an industrial automation project. The decision making in this case resembles the Mintzberg model fairly well. Decision making is correct if all stages of the Mintzberg Model have been gone through in the right sequence. It is clear however that hardly no time was spent on searching for already existing solutions. From our research it appears that the course of decision making and the product documentation are not explicit enough. This always leads to insufficient timely and systematic input of knowledge and experience of all the involved participants in the design process. For example, production engineers should have the opportunity to criticize a newly created design for considerations of producibility. To obtain improvement, particular meetings and appropriate documents are necessary [6].

\section{Nefed for Improving Management Structure}

The phenomena described above and their several causes make it essential to have a better management structure for the design process. Such a management structure must make faster 


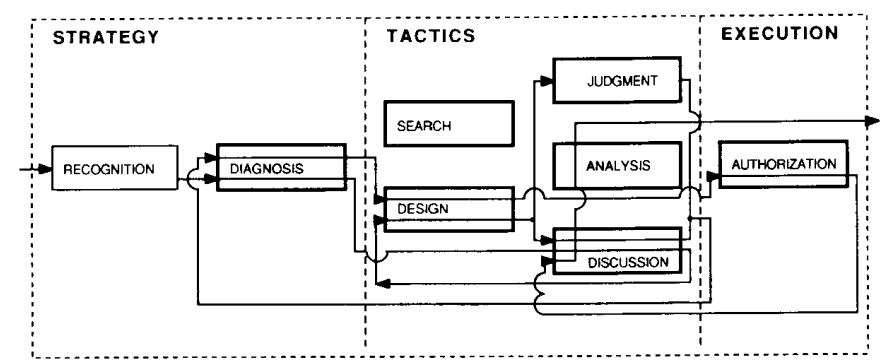

Fig. 3. Real course of decision making in automation project.

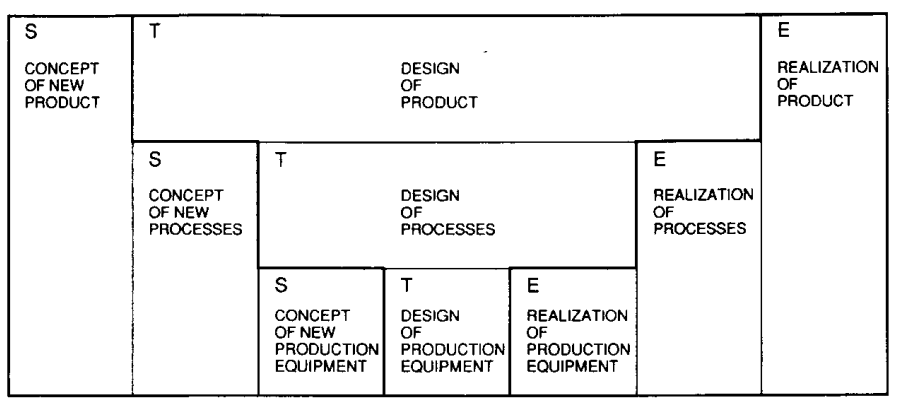

Fig. 4. Complexity of product renewal range.

feedback possible by dividing the relatively long design period into shorter stages as is used in project management [1]. In other words this structure must be a basis for progress control in a project involving throughput time and costs. Furthermore, the earlier mentioned feedback on matters of quality must be incorporated [6].

The management structure must also promote timely and systematic input of as much knowledge and experience as possible in the decision making process and stimulate good communication between designers and other interested parties. This requires a management structure which includes design meetings (DA, PPA, FMEA, and DFP), with an agreed flow of documents forming an essential part.

The decision making cycle elaborated in the present article is based on the assumption that in sorting problems the following three stages must always occur:

1) strategy (S): the problems and standards are laid down here;

2) tactics (T): alternatives are researched and the best solution is selected;

3) execution (E): the design solution is translated into an operational plan.

Each partial stage can itself be regarded as a problem and therefore likewise be subdivided into similar phasing. Fig. 3 also shows, indicated by dotted lines, the relationship between the Mintzberg model and the decision making cycle. Strategy includes recognition and diagnosis, tactics involves search, design, judgment, analysis, and discussion, and execution resembles authorization.

Before discussing the possibility of setting up a managerial structure based on the decision making cycle (strategy, tac- tics and execution), we first shall illustrate the complexity of design processes from the view-point of decision making.

\section{Complexity of the Design Process}

If we apply the thought process described above to the total product-renewal range including the conception, design and realization of the product, processes and production equipment, we obtain a picture as sketched in Fig. 4.

The various phases involve many decisions. Decisions on the product, processes and production equipment concern each the strategy, tactics, and execution. Decisions on the production equipment are embedded in those on the processes. Decisions on the processes are embedded on their turn in those on the product. Even in smaller companies many people with different backgrounds are involved in the design process and are responsible for specific decisions. These large numbers of decisions and the many persons involved make the design process very complex from the view-point of decision making.

If we project the decision making cycle onto the process of designing production equipment the complexity of the design process, from the view-point of decision making, can be illustrated even better. If we regard the production equipment to consist of an hierarchy of interrelated functions, we have a phasing as shown in Fig. 5.

The functions of the machine group can be split up into several functions corresponding with different machines. During the respective phases of designing the machine group or machine or unit, an attempt is always made to translate the functions of a required machine into a set of interrelated functions of units or components. Detailing refers to laying down a solution of a problem in the form of a set of drawings of all components. 


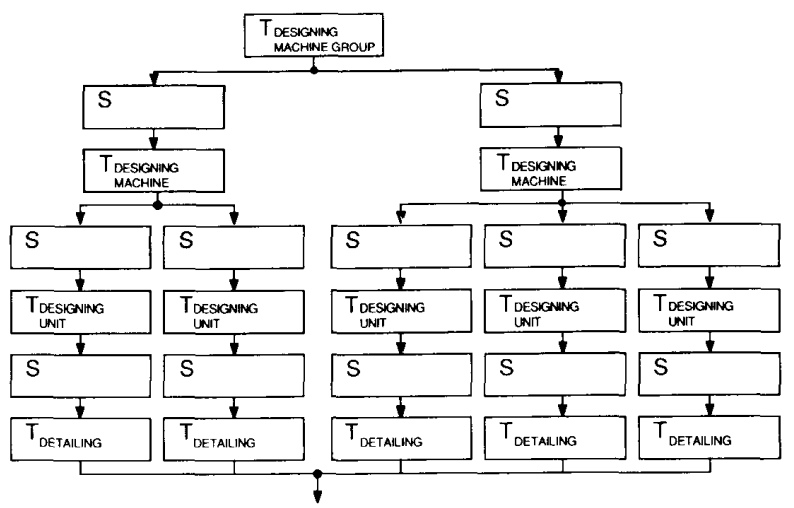

Fig. 5. Complexity of design range of production equipment.

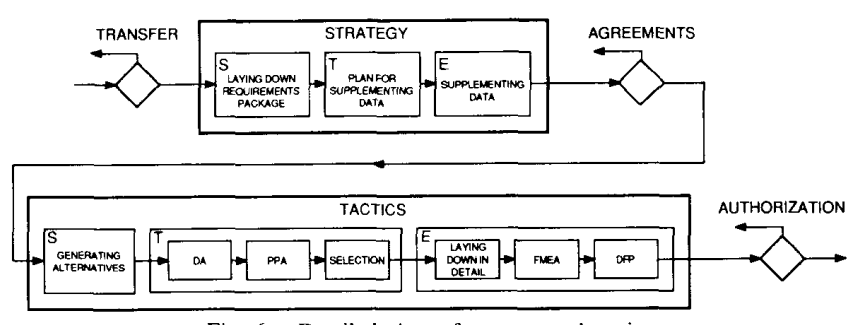

Fig. 6. Detailed view of strategy and tactics.

\section{Design Meetings: DA, PPA, FMEA, And DFP}

In accordance with the decision making cycle we subdivide the strategy and tactics stages again. This subdivision includes a number of part-stages in which three progress controls transfer, agreements and authorization can be embodied. Transfer involves the setting of targets, agreements the proof on the feasibility of the targets and authorization the extent to which the targets are met. This subdivision (see Fig. 6) of the stages strategy and tactics makes it possible to indicate the exact position of DA, PPA, FMEA, and DFP within the decision making-cycle. The sequential part-stages are as follows.

\section{Strategy (S)}

S: Establishing completeness of desired function and package of requirements and wishes.

$\mathrm{T}$ : Planning for supplement of deficiencies.

E: Supplementing the lacking data.

\section{Tactics $(T)$}

S: Generating alternative solutions.

T: Undertaking DA. Here the extent to which the alternative solutions meet the requirements is verified.

Undertaking PPA. The degree to which the various solutions can stand up to deleterious influences from the environment (e.g., changes in market demand).

Choosing a best alternative based on the DA and PPA.

$\mathrm{E}$ : Laying down the best alternative.

Undertaking FMEA; here the emphasis lies on environmental risks that can be involved in the event of failure of a given solution.
Undertaking DFP. Here the emphasis lies on the possible necessity of changing the design for considerations of producibility of parts, assembly (DFA [4]), transportability and measurability.

The design meetings DA, PPA, FMEA, and DFP play an essential role in promoting good communication on the relevant design aspects between designers and other interested parties. The communication must involve the timely and systematic input of knowledge and experience available in an organization in the design process.

DA and PPA mostly involve a number of different alternative solutions and serve to promote a well-balanced selection from such alternatives. In the case of an FMEA and DFP the preference for a given solution has already been expressed and the main issue is the optimization of the solution that has already been worked out in detail. In a PPA the main concern is risk from the environment which may have a bearing on any solution and, in the case of an FMEA, it is the actual failure behaviour of the solution itself.

The DA, PPA, FMEA, and DFP will usually occur at meetings to be convened by the designer. These design meetings cannot succeed without contributions from representatives of the environment of the design process concerned, like product and process developers, and representatives from the trade and production field. For example, these people may contribute by criticizing designs from the view-point of possible changes in market conditions, serviceability, etc.

The prescription in Fig. 6 seems very simple and linear, but can be used as an important guiding principle for structuring all design activities.

In practice it will not be necessary to convene all the design 


\begin{tabular}{|c|c|c|c|c|}
\hline \multicolumn{2}{|c|}{ ASPECTS } & TRANSFEA & AGREEMENTS & AUTHORIZATION \\
\hline \multirow{3}{*}{ 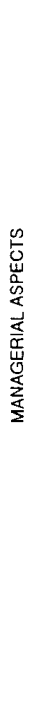 } & QUALITY & $\begin{array}{l}\text { SETTING UP TARGETS } \\
\text { FOR THE DESIGN } \\
\text { RESULT }\end{array}$ & $\begin{array}{l}\text { - IS PRESCRIBED TASK } \\
\text { FEASIBLE? } \\
\text { - IS PRINCIPAL IN } \\
\text { AGREEMENT WITH } \\
\text { INTERPREIATION. } \\
\text { ASSUMPTONS AND } \\
\text { MODIFICATIONS? } \\
\text { - REQUIRED CAPACITIES } \\
\text { AVAILABLE? }\end{array}$ & $\begin{array}{l}\text { DOES SOLUTION } \\
\text { MEET THE RANGE } \\
\text { OF REOUIREMENTS } \\
\text { ANO WISHES? }\end{array}$ \\
\hline & $\begin{array}{l}\text { THROUGHPUT } \\
\text { TIME }\end{array}$ & $\begin{array}{l}\text { SETTING TARGETS } \\
\text { FOR TIME WHEN } \\
\text { DESGN RESULT } \\
\text { CAN BE AUTHORIZED }\end{array}$ & $\begin{array}{l}\text { - WHEN WILL ACTUAL } \\
\text { DESIGN BE READY? } \\
\text { - IS REPLANNING OF } \\
\text { DELIVERY DATE OF } \\
\text { TOIAL PPOOECT } \\
\text { REQUIRED? } \\
\text {-WHAT ARE THE CHANCES } \\
\text { OF TAKING ACTON IF } \\
\text { DELLVERY TIME IS } \\
\text { EXCEEDED? } \\
\text { (RETRENCHMENTS) } \\
\text { - IS REQUIRED CAPACITY } \\
\text { OF AUXILIARY MEANS } \\
\text { REQUIRED? }\end{array}$ & $\begin{array}{l}\text { REPLANNING TOTAL } \\
\text { PROJECT IF } \\
\text { REOUIRED, AS } \\
\text { REGAROS DELIVERY } \\
\text { TIMEAND USING } \\
\text { CAPACITY }\end{array}$ \\
\hline & COSTS & $\begin{array}{l}\text { SETING COST } \\
\text { TARGETS FOR } \\
\text { REOUED DESIGN } \\
\text { ACTIVITIES }\end{array}$ & $\begin{array}{l}\text { WHAT WILL BE THE } \\
\text { COSTS OF ACTUAL } \\
\text { DESIGN? } \\
\text { - CALCULATE COSTS } \\
\text { FOR WHOLE PROJECT } \\
\text { WHAT OPPORTUNITIES } \\
\text { FOR TARING ACTON } \\
\text { ARE AVAILABLE, } \\
\text { IF COSTS BUDGET } \\
\text { EXEEDED? } \\
\text { (RETRENCHMENTS) }\end{array}$ & $\begin{array}{l}\text { BUDGET FOR } \\
\text { THE PROUECT } \\
\text { EXCEEDED? }\end{array}$ \\
\hline \multirow{2}{*}{ 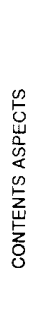 } & INFORMATION & $\begin{array}{l}\text { - IS AVAILABLE } \\
\text { INFORMATION } \\
\text { WELL SET OUT } \\
\text { AND USEFUL? } \\
\text { IAYDOWW } \\
\text { PAROCEDURES FOR } \\
\text { SETING OUT } \\
\text { INFORMATION }\end{array}$ & $\begin{array}{l}\text { - HAVE VARIOUS CHECKS } \\
\text { BEEN CARRIED OUT? } \\
\text { - HAS CORRECT FOPMAT } \\
\text { BEEN USED? } \\
\text { - HAS RECORDING BEEN } \\
\text { DONE FOR DETERMINING } \\
\text { PERFRRMANCE OF } \\
\text { DESIGN PROCESS? } \\
\text { ARE CHANGES ON } \\
\text { PROCEDURE } \\
\text { NECESSARY? }\end{array}$ & $\begin{array}{l}\text { - HAVE CHECKS BEEN } \\
\text { CARRIED OUT? } \\
\text { - IS REPORTING OF } \\
\text { PERFORMANCE } \\
\text { INDICATORS } \\
\text { ADEQUATE? } \\
\text { - HAS CORRECT FORMAT } \\
\text { BEEN USED? } \\
\text { - IS INFORMATION } \\
\text { COMPLETE? }\end{array}$ \\
\hline & ORGANIZATION & $\begin{array}{l}\text { AGREEMENT ABOUT } \\
\text { WHO IS TO BE } \\
\text { RESPONSIBLE }\end{array}$ & $\begin{array}{l}\text { IF NECESSARY, MODIFY } \\
\text { THE ORGANIZATION AND } \\
\text { AMEND THE } \\
\text { RESPONSIBILITIES }\end{array}$ & $\begin{array}{l}\text { REWARD AND/OR } \\
\text { DISMISSAL OF } \\
\text { RESPONSIBLE } \\
\text { PERSONS }\end{array}$ \\
\hline
\end{tabular}

Fig. 7. Activities to be carried out during progress control.

meetings as proposed. Also the persons to be invited will differ for almost every meeting. This depends on, among other things, the size of the design projects and uncertainty level. In so-called high technology industry, where profits come from new concepts, the emphasis will be more on DA and PPA. In companies, for instance automative industry, where design is evolutionary and production quantities are large, FMEA and DFP will become more important.

The prescription is less linear in practice because a design project consists often of paralleled and interrelated subprojects (Figs. 4 and 5). In case of great uncertainty the actual design is not so straight forward but iterative. During a progress control it can be concluded that the designer has to return to earlier decision stages in case he encounters unsurmountable problems.

\section{Progress Controls}

During the various controls (transfer, agreements and authorization) which serve as reasons for convening meetings, the management aspects are used to see whether the project is still running according to plan and/or has to be adjusted because of shortcomings (short-term feedback). The conclu- sions and agreements reached at these meetings are reported tersely in the collective minutes in one single document representing the history of the whole project. It can, moreover, be necessary to introduce changes in the way the project has been organized and information set out. The organization and information aspects comprise the content side of the design process. The main matter involved during the transfer is the setting up of targets, during agreements the proof on the feasibility of the targets, and during authorization the extent to which the available solution meets the targets. Progress controls will always be necessary. These controls serve as important checks for the money supplier to get a better insight in the progress of design projects and keep the involved designers informed of new and changed targets. Of course informal meetings are essential and must be stimulated.

The measures necessary in the course of the various progress controls appear in Fig. 7. The figure can be regarded as the initial step in providing systematically ordered answers to the questions which inevitably arise in the course of progress controls so that designers get the support they need.

For considerable time the computer has been playing an im- 
portant role in the design process. It is one which is mainly evident in such activities as drawing, calculating, simulating, optimizing, etc. [13]. But, it scarcely plays a worthwhile role in support of communication within the product-renewal range. Within this framework and in view of the management structure sketched out on the basis of rational decision making, the computer could be used for several activities (see Fig. 7). These include support of designers in running through the sequence of stages comprising the decision making range and generation of reports in support of the various meetings to be held (short-term feedback).

Important in this approach is that the documents representing the history of the completed projects are filed in the computer and are easily accessible to the designers, projectleaders etc. Furthermore, the computer can support the designers in ordering the data concerned in finished projects. Then these data can be made available, e.g., as checklists, and can be applied both in current projects (feedback in the medium long term) as well as in reorganization of the design process itself (longterm feedback).

\section{Conclusion}

The integration of rational decision making, methodical designing, particular design meetings, and progress controls can give rise to improved manageability of the designing process. Characteristic of such a set-up is the fact that the nature of the DA, PPA, FMEA, and DFP comes out all the more clearly. These are multidisciplinary meetings with the object of promoting timely and systematic input of as much as possible knowledge and experience existing within an organization in the design process.

The approach presented indicates the computer to be capable of giving valuable support to design activities.

The management structure referred to has already been applied in two departments for product development and in an industrial automation department.

\section{REFERENCES}

[1] N. G. Anderson, From Concept to Production: A Management Approach. London: Taylor \& Francis, 1975.

[2] M. M. Andreasen, "The use of systematic design in practice," Design and Synthesis, Amsterdam, The Netherlands: Elsevier Science, 1985, pp. 139-144.

[3] J. M. van Bragt, "Bedrijfsmechanisatie," De Constructeur, no. 1, Jan. 1987.

[4] G. Boothroyd, Automatic Assembly. New York: Marcel Dekker, 1982 .

[5] F. Hansen, "Konstruktionswissenschaft, Grundlagen und Methoden," VEB Verlag Technik, Berlin, 1974.

[6] A. G. Hemels, H. H. van Mal, "Rationele besluitvorming ondersteunt het produkt optimalisatie proces," De Constructeur, no. 6, pp. 20-24, June 1987.

[7] R. A. Howard, "Decision analysis: applied decision theory," Proc. 4th International Conf. Operational Research, 1966, pp. 55-71.
[8] R. A. Howard, "The foundation of decision analysis," IEEE Trans. Syst. Sci. Cybern., vol. SSC-4, no. 3, pp. 211-219, Sept. 1968.

[9] V. Hubka, "Attempts and possibilities for rationalisation of engineering design," Design and Synthesis, Amsterdam, The Netherlands: Elsevier Science, 1985, pp. 133-138.

[10] J. M. Juran, R. W. Peach, "Field performance," Quality Control Handbook, New York: McGraw-Hill, 1974.

[11] C. H. Kepner and B. B. Tregoe, The Rational Manager; a Systematic Approach to Problem Solving and Decision Making. New York: McGraw-Hill, 1965.

[12] C. H. Kepner and B. B. Tregoe, The New Rational Manager. Princeton, $\mathrm{NJ}: 1981$

[13] H. H. van den Kroonenberg, "CAD applications in the creative phases of the methodical design process," $C A P E$ ' 86 , May 1986, pp. 339-348.

[14] H. H. van Mal, "De koppeling van CAD en CAM: de computer als hulpmiddel bij de communicatie in het produktvernieuwingstraject," De Constructeur, no. 3, pp. 62-66, Mar. 1985.

[15] H. Mintzberg, D. Raisinghani, and A. Theoret, "The structure of 'unstructured' decision processes," Administrative Science Quarterly, vol. 21 , pp. 246-275, 1976.

[16] J. M. A. van de Molengraft, M. Bliek, and H. H. van Mal, "Informatiesystemen voor gereedschapsbeheer, prestatiegrafieken van gereedschappen," MB-produktie-techniek, vol. 51, no. 24, pp. 612-616, 1985

[17] K. Roth, Konstruieren mit konstruktionskatalogen. Berlin: Springer-Verlag, 1982

[18] H. J. W. Vliegen, "Beheersing Technische Informatiestroom van bedrijfsmechanisatie-projecten door besluitvorming," Eindhoven University of Technology, Eindhoven. The Netherlands, 1986.

[19] H. D. Voegtlen, "New-product quality," Quality Control Handbook. New York: McGraw-Hill, 1974

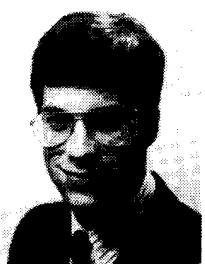

Hugo J. W. Vliegen was born in Voerendaal, The Netherlands, on April 5, 1963. He received the M.Sc. degree in industrial engineering, cum laude, from Eindhoven University of Technology, Eindhoven, The Netherlands in 1986. He is expected to receive the $\mathrm{Ph} . \mathrm{D}$. degree from the Twente University, Enschede, The Netherlands, in 1990.

He is presently Project Leader in Logistics Management with the Domestic Appliances and Persona Care Division of the Philips Corporation, Drachten, The Netherlands.

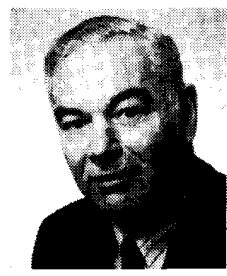

Herman H. van Mal was born in Groningen, The Netherlands, on March 14, 1937. He received the M.Sc. and Ph.D. degrees in physics from Delft University of Technology, The Netherlands, in 1964 and 1976 , respectively.

$\mathrm{He}$ worked at the University of St. Andrews, Scotland, and continued his research in physics at Philips Laboratories, Eindhoven, The Netherlands. In 1975, he began work as a Senior Management Consultant with the Consumer Electronics and Components Division of Philips. He is presently an Associate Professor with the Faculty of Management Science and Industrial Engineering at the University of Technology in Eindhoven.

His research interests are in the area of increasing productivity in industry, including process, control, group technology, and classification. 